\title{
Sorption of Atrazine, Propazine, Deethylatrazine, Deisopropylatrazine and Hydroxyatrazine onto Organovermiculite
}

\author{
Gilberto Abate* and Jorge Cesar Masini
}

Instituto de Química, Universidade de São Paulo, CP 26077, 05513-970 São Paulo-SP, Brazil

\begin{abstract}
Estudou-se a interação de atrazina (AT), propazina (PROP), desetil-atrazina (DEA), deisopropilatrazina (DIA) e hidroxi-atrazina (HAT) com o argilomineral vermiculita saturado com $\mathrm{K}^{+}$(VTK) e com VTK modificada pela incorporação de hexadeciltrimetil-amônio (HDTMA-VT) no espaço interlamelar. A VTK bruta teve interação desprezível com AT, PROP e DEA, interação moderada com DIA e forte interação com HAT. No caso do material HDTMA-VT as porcentagens de remoção em meio aquoso (concentrações iniciais entre 0,05 a 1,00 $\mathrm{mg} \mathrm{L}^{-1}$ ) foram: 56 - 63\% para AT, $43-45 \%$ para DEA, 30 - 24\% para DIA, 12 - 19\% para HAT e 77 - 78\% para PROP. As taxas de sorção de AT, DEA e PROP em HDTMA-VT foram significativamente aumentadas com relação a VTK. Força iônica e pH tiveram pouca influência na sorção. A dessorção dos compostos previamente sorvidos sobre os minerais HDTMA-VT variou de 20 a 30\% após um tempo de contacto de $24 \mathrm{~h}$.
\end{abstract}

The interaction of atrazine (AT), propazine (PROP), deethylatrazine (DEA), deisopropylatrazine (DIA) and hydroxyatrazine (HAT) was studied with the clay mineral vermiculite saturated with $\mathrm{K}^{+}$ (VTK), and with the mineral modified by insertion of hexadecyltrimethyl-ammonium (HDTMAVT) in the interlayer of VTK. The crude VTK exhibited negligible interaction with AT, PROP and DEA, moderate interaction with DIA and strong interaction with HAT. For the HDTMA-VT materials, removal percentages from aqueous medium for initial concentrations between 0.05 and $1.00 \mathrm{mg} \mathrm{L}^{-1}$ were 56 to $63 \%$ for AT, 43 to $45 \%$ for DEA, 12 to $19 \%$ for HAT and 77 to $78 \%$ for PROP. Sorption of AT, DEA and PROP onto HDTMA-VT was significantly enhanced in comparison to VTK. Ionic strength and $\mathrm{pH}$ had no significant influence on the sorption process. Desorption of all compounds from HDTMA-VT after $24 \mathrm{~h}$ of contact time was between 20 and $30 \%$ of the amount initially adsorbed.

Keywords: atrazine, atrazine metabolites, propazine, vermiculite, sorption, hexadecyltrimethylammonium

\section{Introduction}

The large use of chemicals in agriculture, especially herbicides, has been a serious environmental concern because of the potential run-off and leaching of these compounds through the soil, contaminating surface and ground waters. Weedkillers represent about $50 \%$ of the total of pesticides employed in agriculture. In Brazil, approximately $160,000 \mathrm{t}$ of these compounds were utilized in 2002, especially in crops of soybean, sugarcane, maize, wheat, citrus, rice and coffee. ${ }^{1}$ Symmetrical triazines ( $s$-triazines) are largely used as herbicides, with especial emphasis to atrazine (2-chloro4-ethylamino-6-isopropylamine-s-triazine), which has a selective action in the pre and post-emergence in

* e-mail: gilbertoabate@ig.com.br agricultural soils and forestry applications. Because of the large use of atrazine (AT) to control annual grasses and broad-leaved weeds in several crops, in roadside verges and golf courses, intense research has been performed to investigate its environmental impacts. ${ }^{2-6}$

Several authors have reported the presence of AT and its metabolites in surface and ground waters, as well as other $s$-triazines such as simazine, ametryne and propazine. ${ }^{7}$ Although the presence of AT metabolites is indicative of herbicide degradation, some of them, especially deethylatrazine (DEA) and deisopropylatrazine (DIA), have similar toxicity, greater water solubility and weaker interaction with soil components than the parent herbicide. ${ }^{4}$

Clay minerals are major components of mineral phases of soils, sediments and suspended particles in natural waters. They have the ability to interact with a great number of pollutants, especially heavy metal ions, as a result of 
the exchange of interlamelar cations, mainly $\mathrm{Na}^{+}$and $\mathrm{Ca}^{2+} .8,9$ On the other hand, the presence of these alkaline metal ions imparts a hydrophilic character to the mineral surface. Thus, clay minerals are not efficient adsorbents for organic species because of the strong competition with the polar water molecules..$^{10}$ The nature of pollutant and adsorbent, as well as environmental conditions such as $\mathrm{pH}$ and ionic strength, do influence the sorption processes. According to Laird et al. ${ }^{11}$ the sorption of atrazine on smectite decreases with increasing the surface charge density, suggesting that the herbicide is adsorbed as neutral species, a fact that may be explained by the atrazine $\mathrm{pK}_{\mathrm{a}}$ of 1.7. Nevertheless, even if the $\mathrm{pH}$ of the bulk solution is above the $\mathrm{pK}_{\mathrm{a}}$ of the compound, protonation of the $s$-triazines ${ }^{12}$ may occur in the interlayer waters, favoring the adsorption. ${ }^{9}$ Herwig et al.,${ }^{13}$ demonstrated the influence of the hydrolysis constant of the interlayer cations $\left(\mathrm{Na}^{+}\right.$, $\mathrm{Ca}^{2+}, \mathrm{Ni}^{2+}, \mathrm{Cu}^{2+}$ and $\mathrm{Fe}^{3+}$ ) on the adsorption, verifying that the most hydrolysable ion $\left(\mathrm{Fe}^{3+}\right)$ provided the greater adsorption rates. This was explained by the higher acidity in the interlayer water in comparison to the bulk solution, favoring the protonation of the compound, and so, the adsorption by electrostatic attractions to the negative charges of the mineral surface. This is in agreement with Celis et al., ${ }^{14}$ who verified an enhancement of hexazinone adsorption onto iron saturated montmorillonite in comparison to the interlayer cations $\mathrm{K}^{+}, \mathrm{Na}^{+}$or $\mathrm{Mg}^{2+}$. The authors emphasize that the protonation of weakly basic pesticides favors the adsorption of these compounds as their cationic forms by ion exchange mechanism.

Because of the low cost and ready availability of clay minerals, great attention has been driven to the modification of the their properties, aiming several technological applications. ${ }^{15-17}$ Pillarization is one of the modifications often designated to environmental applications, ${ }^{12,15,16,18}$ consisting in the intercalation of a polynuclear hydroxyl trivalent metal cation, for instance, $\mathrm{Al}^{3+}, \mathrm{Zr}^{3+}, \mathrm{Cr}^{3+}, \mathrm{Fe}^{3+}$ and $\mathrm{Ti}^{3+}$, between the layers, followed by heating. This process provides the development of interlayer metal oxide pillars. As a consequence, an increase in the superficial area and porosity is expected, and hence, an enhancement of the adsorption capacity. Another modification process is based on the exchange of the inorganic cations by organic ones, especially alkylammonium cations, which keep apart the aluminosilicate layers, resulting flexible pillars due to the mobility of the alkyl chains. ${ }^{19}$ This modification aims to increase the hydrophobic character of the mineral surface, enhancing the affinity by organic compounds. Depending on the organic cation structure and its uptake into the clay gallery, the organoclay may have different hydrophobic properties. This is an important feature because the treatment of the mineral phase can be adjusted according to the needs. As a result, the organoclays may be employed for removal of several pollutants in water, for instance, heavy metal ions, ${ }^{17,20}$ inorganic anions such as chromate ${ }^{21}$ and organic compounds such as benzene, toluene, ethylbenzene and xylene isomers; ${ }^{22}$ benzene, trichloroethene and 1,2dichlorobenzene; ${ }^{23}$ naphthalene and phenanthrene ${ }^{24}$ and bacteria ${ }^{25}$. Several studies have been driven to investigate either, the interactions between the organoclays and herbicides aiming their removal from water, ${ }^{26-28}$ or the development of formulations with controlled releasing of the active component in soils..$^{14,29,30}$

Vermiculite is a clay mineral with great availability in Brazil and other countries such as Australia, China, Kenya, South Africa, USA and Zimbabwe. Contrarily to montmorillonite, which has been extensively studied, few researches employing modified vermiculite as adsorbent have been described. The goal of this paper is to investigate the interaction of the raw and organically modified vermiculite with the herbicides atrazine and propazine, as well as the atrazine metabolites: DEA, DIA and HAT.

\section{Experimental}

\section{Apparatus and reagents}

A LC 9A Shimadzu high performance liquid chromatograph (HPLC), equipped with a SPD 6 AV UV detector, and the LC Workstation Class-LC 10 software was used in all experiments for quantification of atrazine, propazine and the atrazine metabolites. A SB C-18 Zorbax - HP column ( $3.5 \mu \mathrm{m}, 150 \times 4.6 \mathrm{~mm})$ connected to a C-18 Phenomenex guard column was employed. Sample injection was made with a rotary Rheodyne valve using a $20 \mu \mathrm{L}$ sample loop. A Metrohm 654 potentiometer (precision of $0.1 \mathrm{mV}$ or 0.001 units of $\mathrm{pH}$ ) was used for $\mathrm{pH}$ measurements. The surface area and pore volume were obtained from BET measurements of $\mathrm{N}_{2}$ adsorption isotherms using a Gemini 2375 V5.00 instrument from Micromeritics Instr. Corp. The basal spacing was determined by X-ray diffraction (XRD) using a Siemens D-5000 diffractometer. Carbon, hydrogen and nitrogen contents were determined by elemental analysis using a Perkin-Elmer Analyzer 2400.

The analytical standards of atrazine (AT), deethylatrazine (DEA), desisopropylatrazine (DIA), hydroxyatrazine (HAT) and propazine (PROP) were supplied by Riedel-de Haën. Their structures and some physicochemical properties are listed in Table 1. Stock solutions (1000 $\left.\mathrm{m} \mathrm{L}^{-1}\right)$ were prepared in methanol (HPLC grade). HAT was previously dissolved in $1 \mathrm{~mL}$ of $1.0 \mathrm{~mol}$ 
$\mathrm{L}^{-1} \mathrm{HCl}$ solution and diluted with methanol. These standards, solids or solutions were stored in freezer at $-18{ }^{\circ} \mathrm{C}$. Acetonitrile and methanol (HPLC grade) were purchased from JT Baker. The hexadecyltrimetilammonium bromide (HDTMA) was purchased from Merck, as well as the other reagents used in this work. Water used in all experiments was distilled and deionized using the NANOpure II (Sybron Barnstead) system.

\section{Sample preparation}

Vermiculite clay mineral (VT) was supplied by Eucatex Química e Mineral Ltda., from the Massapê mine located in Paulistana, PI, Brazil, with grains $<1 \mathrm{~mm}$. The material was ground, and the fraction between 0.27 and $56 \mu \mathrm{m}$ was separated by decantation according to described elsewhere. ${ }^{31}$ Approximately five grams of this vermiculite were treated with $0.050 \mathrm{~mol} \mathrm{~L}^{-1} \mathrm{HCl}$ solution under agitation in an orbital shaker for $30 \mathrm{~min}$. The solids were centrifuged and washed once with $40 \mathrm{~mL}$ of deionized water. Afterward, the clay mineral was equilibrated with $25 \mathrm{~mL}$ of $1.0 \mathrm{~mol} \mathrm{~L}^{-1} \mathrm{KCl}$ solution for $30 \mathrm{~min}$, and the solids separated by centrifugation. This step was repeated twice in order to obtain a homoionic potassium VT suspension (VTK). The solids were then washed four times with deionized water, being separated by centrifugation, and dispersed in approximately $100 \mathrm{~mL}$ of deionized water. The concentrations of these stock solutions were determined by the dry weight of homogenized $1.00 \mathrm{~mL}$ aliquots. The cation exchange capacity (CEC) of VTK was $1.17 \pm 0.01 \mathrm{mmol} \mathrm{g}^{-1}$, determined in triplicate by the method of sodium saturation. ${ }^{32}$

\section{Adsorption of HDTMA}

The organic vermiculite was prepared by cation exchange with a 10 mmol L-1 HDTMA solution. Under vigorous stirring, a suitable volume of homogenized VTK suspension was added to a HDTMA solution in order to provide a relation of 0.5 (HDTMA-VT ${ }_{0.5}$ ) and 1.0 (HDTMA-VT ${ }_{1.0}$ ) of the CEC. According to the findings of Klapyta et al. ${ }^{33}$ higher proportions of HDTMA do not enhance adsorption. The suspensions were kept under agitation in an orbital shaker for $24 \mathrm{~h}$ at room temperature, and the products were washed five times with $40 \mathrm{~mL}$ of deionized water, with the phase separation being made by centrifugation. These organoclays were freeze-dried, crushed and dried at $60^{\circ} \mathrm{C}$ for $48 \mathrm{~h}$. This last step was repeated for the VTK suspension, after a proper separation of the solid phase by centrifugation. All solids were stored in a desiccator.

\section{Sorption and desorption experiments}

These experiments were performed individually for AT, DEA, DIA, HAT and PROP employing the batch equilibration approach. A mass of $30 \mathrm{mg}( \pm 0.1 \mathrm{mg})$ of each adsorbent was weighted in seven glass vials with capacity of $4 \mathrm{~mL}$. Next, $3.00 \mathrm{~mL}$ of the solution containing the studied compound, with concentrations between 50 and $1,000 \mu \mathrm{g} \mathrm{L}^{-1}$ were added to glass vials, which were closed, protected from light and kept under gentle agitation for $24 \mathrm{~h}$ on an orbital shaker programmed at $140 \mathrm{rpm}$. In parallel, five standards with concentrations between 5.0 and $1,000 \mu \mathrm{g} \mathrm{L}^{-1}$, together with the blank solution, were submitted exactly to the same procedure used for the sorption experiments. After $24 \mathrm{~h}$ of contact time the $\mathrm{pH}$ of the suspensions were measured and the solid phases were separated by centrifugation for $15 \mathrm{~min}$ at 2,600 g. Afterwards, $2.70 \mathrm{~mL}$ of the supernatant were withdrawn and filtered through $0.45 \mathrm{~mm}$ Durapore membrane Millex ${ }^{\circledR}$ from Millipore. These solutions were buffered with a suitable volume of $1.0 \mathrm{~mol} \mathrm{~L}^{-1}$ ammonium acetate buffer ( $\mathrm{pH} 4.5)$, being the concentrations determined by HPLC under isocratic elution and UV detection. Table 2 summarizes the HPLC conditions.

Table 1. Structures and some physicochemical properties of AT, DEA, DIA, HAT and PROP

\begin{tabular}{|c|c|c|c|c|c|c|}
\hline$s$-triazines & & Position & & & Characteristics & \\
\hline & 2 & 4 & 6 & $\begin{array}{l}\text { Molar mass } \\
\left(\mathrm{g} \mathrm{mol}^{-1}\right)\end{array}$ & $\begin{array}{l}\text { Water solubility } \\
\qquad\left(\mathrm{mg} \mathrm{L}^{-1}\right)\end{array}$ & $\mathrm{pK}_{\mathrm{a}}$ \\
\hline $\mathrm{AT}$ & - chloro & - ethyl & - isopropyl & 215.68 & $70^{a}$ & $1.68^{\mathrm{a}}$ \\
\hline DEA & - chloro & - amino & - isopropyl & 187.68 & $340^{\mathrm{b}}$ & $1.65^{\circ}$ \\
\hline DIA & - chloro & - ethyl & - amino & 173.68 & $650^{\mathrm{b}}$ & $1.58^{\circ}$ \\
\hline HAT & - hydroxi & - ethyl & - isopropyl & 197.23 & $7^{b}$ & $5.15^{\circ}$ \\
\hline PROP & - chloro & - isopropyl & - isopropyl & 230.09 & $8.6^{\mathrm{a}}$ & $1.85^{\mathrm{a}}$ \\
\hline
\end{tabular}

${ }^{a}$ Ref. 34; ${ }^{\mathrm{b}}$ Ref. $35 ;{ }^{\mathrm{c}}$ Ref. 36. 
The desorption experiments were performed adding 2.70 $\mathrm{mL}$ of deionized water to glass vials containing the adsorbing material and the remaining $0.30 \mathrm{~mL}$ of the herbicides or metabolite solution. ${ }^{5}$ The vials were protected from light and shaken for $24 \mathrm{~h}$ on an orbital shaker at $140 \mathrm{rpm}$. After 24 $\mathrm{h}$ the suspensions were centrifuged and the supernatant phase was treated as in the sorption experiments and analyzed by the HPLC method. All sorption and desorption experiments were performed at the ambient temperature, controlled at 25 $\pm 2{ }^{\circ} \mathrm{C}$. All experiments were performed at $\mathrm{pH} 7.3$.

\section{Influence of $\mathrm{pH}$ on the sorption process}

To study the influence of $\mathrm{pH}$ on sorption, a procedure similar to the one described in the previous section was used, with the following modifications: in a set of experiments the suspensions $\mathrm{pH}$ were adjusted to 4.9 and 2.4 by adding 0.1 mol L ${ }^{-1} \mathrm{HCl}$ solution. The initial concentration of each compound was $250 \mu \mathrm{g} \mathrm{L}^{-1}$. The suspensions were equilibrated for $24 \mathrm{~h}$, followed by centrifugation of the supernatant phases, which were analyzed by HPLC (Table 2).

Table 2. HPLC conditions for determining the AT, DEA, DIA, HAT and PROP concentrations

\begin{tabular}{ccccc}
\hline Compound & $\begin{array}{c}\text { Mobile } \\
\text { phase } \\
\left(\% \mathrm{NH}_{4} \mathrm{Ac} /\right. \\
\% \mathrm{ACN}^{\mathrm{a}}\end{array}$ & $\begin{array}{c}\text { Wavelength } \\
(\mathrm{nm})\end{array}$ & $\begin{array}{c}\text { Retention } \\
\text { time } \\
(\mathrm{min})\end{array}$ & $\begin{array}{c}\text { Limit of } \\
\text { Detection } \\
\left(\mathrm{mg} \mathrm{L}^{-1}\right)\end{array}$ \\
\hline $\mathrm{AT}$ & $50 / 50$ & 220 & 4.14 & 0.5 \\
$\mathrm{DEA}$ & $65 / 35$ & 214 & 3.04 & 0.5 \\
$\mathrm{DIA}$ & $65 / 35$ & 214 & 2.30 & 0.5 \\
$\mathrm{HAT}$ & $65 / 35$ & 236 & 2.67 & 1.0 \\
PROP & $50 / 50$ & 220 & 5.78 & 0.5
\end{tabular}

a $2.5 \mathrm{mmol} \mathrm{L}^{-1}$ ammonium acetate buffer ( $\mathrm{pH} 4.5$ ) and acetonitrile $(\mathrm{ACN}) \%(\mathrm{v} / \mathrm{v})$.

\section{Data treatment}

Sorption data were treated by the linearized Freundlich equation:

$\log (q)=\log K_{f}+(n) \log C$

Where $q$ is the concentration of the studied compound in the solid phase $\left(\mu \mathrm{mol} \mathrm{kg}{ }^{-1}\right), C$ is the solution concentration $(\mu \mathrm{mol}$ $\mathrm{L}^{-1}$ ) after a given contact time ( $24 \mathrm{~h}$ in the present study), and $K_{f}$ and $n$ are empirical constants related to sorption.

The sorption distribution coefficients $K_{d}$ were calculated with the equation:

$$
K_{d}=q / C
$$

The sorption coefficients were normalized to the organic carbon (OC) content of the material using the equation 3 , providing the $K_{O C}$ values.

$$
K_{O C}=\left(\frac{K_{d}}{\% O C}\right) 100
$$

\section{Results and Discussion}

\section{Characterization}

Table 3 shows the results of elemental composition, BET surface area, pore volume and the basal spacing $\mathrm{d}(001)$ of the starting VTK, and the modified HDTMA-VT ${ }_{0.5}$ and HDTMA-VT ${ }_{1.0}$ vermiculites. A great reduction of the surface area and pore volume was observed for the modified vermiculite, a fact that can be explained by the clogging of the interlayer space by the large HDTMA molecules, which hinder the $\mathrm{N}_{2}$ access to the internal surface of the clay mineral. This is in agreement with Bartelt-Hunt et $a l .{ }^{23}$ who determined surface areas of several different HDTMA ratios for a bentonite sample, verifying a decrease in the surface area with the increase in the carbon uptake. The basal spacing of HDTMA-VT ${ }_{0.5}$ and HDTMA-VT were 13.7 and $14.4 \AA$, respectively. Despite of the higher basal spacing observed for HDTMA- $\mathrm{VT}_{1.0}$, the surface area $\left(11.4 \mathrm{~m}^{2} \mathrm{~g}^{-1}\right)$ of this material was smaller than observed for HDTMA-VT $0.5\left(13.7 \mathrm{~m}^{2} \mathrm{~g}^{-1}\right)$. This fact can also be explained by larger amount of HDTMA hindering the access of $\mathrm{N}_{2}$ to the internal surface of the mineral. The elemental analysis is coherent with the incorporation of $\mathrm{C}, \mathrm{H}$ and $\mathrm{N}$ in the mineral structure because these elements were not detected in the starting material (VTK).

\section{Sorption experiments}

Figure 1 shows the sorption and desorption curves of AT, DEA, DIA, HAT and PROP. In all cases $C$-type isotherms (constant partitioning) were observed, indicating a constant relative affinity of the solute molecules by the sorbent. ${ }^{9}$ The sorption Freundlich parameters reported in

Table 3. Elemental analysis, surface area (BET), pore volume and

\begin{tabular}{|c|c|c|c|c|c|c|}
\hline \multirow[t]{2}{*}{ Material } & \multicolumn{3}{|c|}{$\begin{array}{c}\text { Elemental analysis } \\
(\%)\end{array}$} & \multirow[t]{2}{*}{$\begin{array}{c}\text { BET } \\
\left(\mathrm{m}^{2} \mathrm{~g}^{-1}\right)\end{array}$} & \multirow{2}{*}{$\begin{array}{c}\text { Pore } \\
\text { volume } \\
\left(\mu \mathrm{L} \mathrm{g}^{-1}\right)\end{array}$} & \multirow{2}{*}{$\begin{array}{c}\mathrm{d}(001) \\
(\AA)\end{array}$} \\
\hline & $\mathrm{C}$ & $\mathrm{H}$ & $\mathrm{N}$ & & & \\
\hline VTK & - & - & - & 31.4 & 14 & 10.8 \\
\hline HDTMA-VT $_{0.5}$ & 11.5 & 2.78 & 0.70 & 13.7 & 5.2 & 13.7 \\
\hline HDTMA-VT $_{1.0}$ & 18.9 & 4.11 & 1.18 & 11.4 & 4.2 & 14.4 \\
\hline
\end{tabular}
basal spacing $\mathrm{d}(001)$ of the studied sorbents 
Table 4 shows that $n$ values are very close to 1 , indicating that the partition model properly represents the experimental data $\left(r^{2}>0.99\right)$. This means that non-specific interactions occur between solute and sorbent. From the $K_{f}$ values, the following sorption order can be depicted for both HDTMA modified vermiculites: HAT $<$ DIA $<$ DEA $<$ AT $<$ PROP. For the potassium-saturated vermiculite (VTK), the $K f$ values indicate the following sorption order: $\mathrm{PROP}<\mathrm{DEA}<\mathrm{AT}<\mathrm{DIA}<\mathrm{HAT}$. The deviation of linearity observed in the sorption of HAT onto VTK $(n=$ $0.51)$ is consistent with specific interactions between solute and sorbent, which might involve partial protonation of HAT ( $\mathrm{pK}_{\mathrm{a}}$ 5.15), either in the solution or in the interlayer waters of the clay mineral, ${ }^{13,14}$ followed by ion-exchange processes with $\mathrm{K}^{+}$and/or hydrogen bonding formation with hydroxyl groups on the mineral surface. The suspension $\mathrm{pH}$ in VTK experiments was around of 7.1, implying that only about $1 \%$ of HAT is protonated in solution. After incorporation of HDTMA the surface is made hydrophobic, decreasing significantly the sorption of HAT in comparison to the other compounds. This finding gives support to the hypothesis of electrostatic attractions or hydrogen bonding of HAT with VTK, despite the small proportion of the protonated species under the experimental $\mathrm{pH}$ utilized.

The sorption of PROP, which was negligible onto VTK, hence not shown in Figure 1, was significantly enhanced onto HDTMA-VT materials, as can be noticed by the markedly increase in the $K f$ values reported in Table 4. Comparing sorption of PROP, AT, DEA and DIA one can verify the stronger affinity of PROP by the HDTMA-VT materials. The $\mathrm{pK}_{\mathrm{a}}$ values of all these compounds do not differ significantly from each other and are very low (Table 1), denoting that protonation is not likely to occur in the suspension $\mathrm{pH}$ in which the experiments were performed (between 7.0 - 7.5). In this case the sorption sequence can be explained by the water solubility of the compounds, which increases in the order PROP $<$ AT $<$ DEA $<$ DIA (Table 1), so that the hydrophobicity enhancement of HDTMAVT materials favors the sorption of the compounds less soluble in water. Such a behavior was also observed by
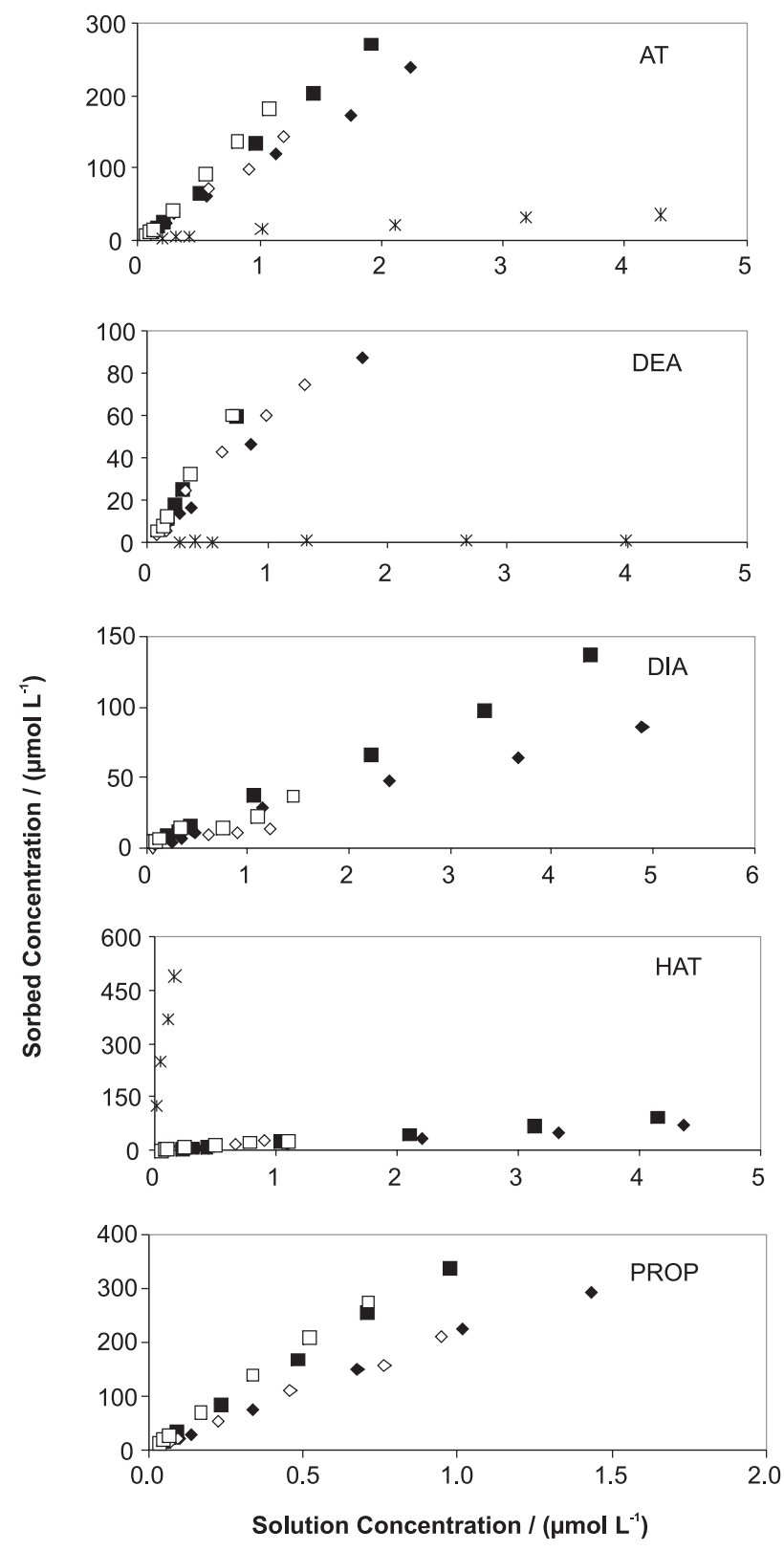

Figure 1. Sorption (black symbols) and desorption curves (white symbols) of AT, DEA, DIA, HAT and PROP in $10.0 \mathrm{~g} \mathrm{~L}^{-1}$ suspensions of VTK $(*)$; $\operatorname{HMDT}_{-} \mathrm{VT}_{0.5}(\bullet, \diamond)$ and $\operatorname{HDTMA}^{-V_{1.0}}(\mathbf{\square}, \square)$.

Table 4. Freundlich parameters: $K_{f}\left(\mu \mathrm{mol}^{1-\mathrm{n}} \mathrm{L}^{\mathrm{n}} \mathrm{kg}^{-1}\right)$ and $n$ for sorption of AT, DEA, DIA, HAT and PROP onto HDTMA-VT materials

\begin{tabular}{|c|c|c|c|c|c|c|c|c|c|}
\hline \multirow[b]{3}{*}{ Compound } & \multicolumn{9}{|c|}{ Materials } \\
\hline & \multicolumn{4}{|c|}{ HDTMA-VT $_{0.5}{ }^{\mathrm{a}}$} & \multicolumn{2}{|c|}{ HDTMA-VT $_{1.0}{ }^{\mathrm{a}}$} & \multicolumn{3}{|c|}{$\mathrm{VTK}^{\mathrm{a}}$} \\
\hline & $N$ & $K_{f} a d s$ & $r^{2}$ & $n$ & $K_{f} a d s$ & $r^{2}$ & $n$ & $K_{f} a d s$ & $r^{2}$ \\
\hline AT & $1.02 \pm 0.02$ & $102 \pm 3$ & 0.999 & $1.08 \pm 0.01$ & $138 \pm 2$ & 0.999 & $0.90 \pm 0.05$ & $10.5 \pm 0.7$ & 0.992 \\
\hline DEA & $0.97 \pm 0.02$ & $50 \pm 1$ & 0.997 & $0.99 \pm 0.02$ & $81 \pm 2$ & 0.997 & $0.8 \pm 0.2$ & $0.45 \pm 0.10$ & 0.87 \\
\hline DIA & $0.98 \pm 0.05$ & $20 \pm 1$ & 0.986 & $0.90 \pm 0.02$ & $35 \pm 1$ & 0.998 & $0.93 \pm 0.04$ & $16.6 \pm 0.8$ & 0.994 \\
\hline HAT & $1.07 \pm 0.04$ & $14.8 \pm 0.7$ & 0.993 & $1.00 \pm 0.02$ & $21.9 \pm 0.4$ & 0.998 & $0.51 \pm 0.03$ & $(1.2 \pm 0.1) \times 10^{3}$ & 0.997 \\
\hline PROP & $0.97 \pm 0.01$ & $214 \pm 5$ & 0.999 & $0.97 \pm 0.02$ & $355 \pm 17$ & 0.998 & & - & - \\
\hline
\end{tabular}

${ }^{\text {a }}$ Results correspond to the average of a duplicate of experiments. 
Celis et al..$^{14}$ for sorption of hexazinone onto organically modified montmorillonite. The $K_{f}$ values obtained for PROP and AT is in good agreement the value of 97 to 103 mmol ${ }^{1-n} L^{n} \mathrm{~kg}^{-1}$ reported by Cruz-Guzman et al. ${ }^{28}$ for the binding of simazine (another s-triazine) to HDTMA modified montomorillonite.

Table 5 presents the $K_{d}$ and $K_{O C}$ values for sorption of AT, DEA, DIA, HAT and PROP onto the organically modified vermiculite. Because the sorption isotherms are linear, with the $n$ parameter of the Freundlich equation approaching 1 , the $K_{d}$ values are close to the $K_{f}$ ones, implying in the same order of affinity previously discussed. Despite the apparently higher affinity of all compounds by the HDTMA-VT ${ }_{1.0}$ material, which exhibited higher $K_{d}$ values in comparison to the ones obtained with HDTMA$\mathrm{VT}_{0.5}$, the normalization effected as a function of organic carbon content reveals that affinities, expressed as $K_{O C}$, are not significantly different for both forms of organically modified vermiculites.

\section{Influence of $p H$ and ionic strength}

Figure 2 shows the removal percentages of AT, DEA, DIA, HAT and PROP from $250 \mu \mathrm{g} \mathrm{L}^{-1}$ solutions as a function of the $\mathrm{pH}$, which was studied in the range between 2.4 and 7.5, using the HDTMA-VT $\mathrm{V}_{1.0}$ material. The $\mathrm{pH}$ influence was not very important, and only a small decrease in the sorption percentages was observed with the decrease in the $\mathrm{pH}$ for AT, DEA, DIA and PROP. For HAT, however, the removal percentage increased from 6.6 to $19 \%$ with the $\mathrm{pH}$ increase from 4.9 to 7.3. This fact confirms that the studied compounds are preferentially sorbed as neutral species onto the organic phase of the modified vermiculites. Adsorbed percentages of all compounds was enhanced by only about $4 \%$ upon increasing the salt content from 5 to $100 \mathrm{mmol} \mathrm{L}^{-1} \mathrm{KCl}$, denoting a small effect of ionic strength, which is also in agreement with predominance of neutral forms of solutes in solution.

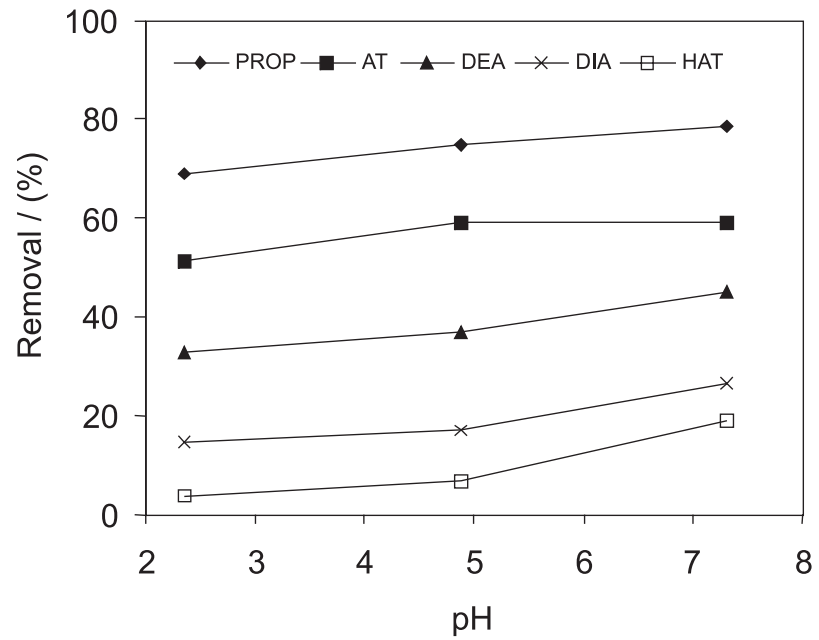

Figure 2. Influence of $\mathrm{pH}$ on the sorption process of AT, DEA, DIA, HAT and PROP onto a $10.0 \mathrm{~g} \mathrm{~L}^{-1}$ suspension of HMDT-VT $\mathrm{H}_{10}$. The initial concentration of each compound was $250 \mu \mathrm{g} \mathrm{L} \mathrm{L}^{-1}$.

\section{Desorption experiments}

Desorption isotherms related the amount of the chemical retained by the vermiculite materials to the solution concentration after $24 \mathrm{~h}$ of contact time (Figure 1). The curves were properly fitted by the linearized Freundlich equation, with all $r^{2}>0.98$ (Table 6). Larger desorption $K_{f}$ values denote greater proportion of the chemical retained in the solid phase, so that the following desorption order can be depicted: DIA $>$ HAT $>$ DEA $>$ AT $>$ PROP for both organically modified vermiculites. In the case of experiments performed with VTK, the compounds AT, DEA DIA and PROP were quantitatively desorbed (or not previously sorbed, as occurred with PROP) so that it was not possible to compute the Freundlich parameters. Hydroxyatrazine, on the other hand, remained strongly sorbed onto VTK, especially for the initial concentrations between 50 and $100 \mu \mathrm{g} \mathrm{L} \mathrm{L}^{-1}$ for which the desorbed concentrations were lower than the detection limit of the chromatographic method.

The $K_{d}$ and $K_{O C}$ for the desorption process are shown in Table 7. For AT, DEA and PROP the $K_{d}$ values were larger

Table 5. Values of distribution coefficient $\left(K_{d}\right)$ and distribution coefficient normalized to the organic carbon content $\left(K_{O C}\right)$ obtained in the sorption experiment of AT, DEA, DIA, HAT and PROP onto the HDTMA modified vermiculites

\begin{tabular}{lcccc}
\hline Compound & \multicolumn{3}{c}{ Materials } \\
\cline { 2 - 5 } & \multicolumn{3}{c}{ HDTMA-VT $_{0.5}{ }^{\mathrm{a}}$} & \multicolumn{2}{c}{ HDTMA-VT $_{1.0}^{\text {a }}$} \\
\cline { 2 - 5 } & $K_{d} /\left(\mathrm{L} \mathrm{kg}^{-1}\right)$ & $K_{O C} /\left(\mathrm{L} \mathrm{kg}^{-1}\right)$ & $145 \pm 1$ & $K_{O C} /\left(\mathrm{L} \mathrm{kg} \mathrm{k}^{-1}\right)$ \\
AT & $104 \pm 3$ & $404 \pm 26$ & $81 \pm 1$ & $767 \pm 5$ \\
DEA & $47 \pm 1$ & $409 \pm 9$ & $30.0 \pm 0.8$ & $429 \pm 5$ \\
DIA & $17.2 \pm 0.8$ & $235 \pm 10$ & $22.7 \pm 0.4$ & $159 \pm 4$ \\
HAT & $16.0 \pm 0.6$ & $139 \pm 5$ & $348 \pm 5$ & $116 \pm 2$ \\
PROP & $207 \pm 5$ & $1878 \pm 45$ & $2063 \pm 30$ \\
\hline
\end{tabular}

${ }^{a}$ Results correspond to the average of a duplicate of experiments. 
Table 6. Freundlich parameters: $K_{f}\left(\mu \mathrm{mol}^{1-\mathrm{n}} \mathrm{L}^{\mathrm{n}} \mathrm{kg}^{-1}\right)$ and $n$ for desorption of AT, DEA, DIA, HAT and PROP onto HDTMA-VT materials

\begin{tabular}{|c|c|c|c|c|c|c|c|c|c|}
\hline \multirow[b]{3}{*}{ Compound } & \multicolumn{9}{|c|}{ Materials } \\
\hline & \multicolumn{3}{|c|}{ HDTMA-VT $_{0.5}{ }^{\mathrm{a}}$} & \multicolumn{3}{|c|}{ HDTMA-VT $_{1.0}{ }^{\mathrm{a}}$} & \multicolumn{3}{|c|}{$\mathrm{VTK}^{\mathrm{a}}$} \\
\hline & $N$ & $K_{f} d e s$ & $r^{2}$ & $n$ & $K_{f} d e s$ & $r^{2}$ & $n$ & $K_{f} d e s$ & $r^{2}$ \\
\hline AT & $1.04 \pm 0.03$ & $123 \pm 6$ & 0.999 & $1.08 \pm 0.02$ & $199 \pm 5$ & 0.999 & - & - & - \\
\hline DEA & $0.99 \pm 0.05$ & $65 \pm 5$ & 0.991 & $1.10 \pm 0.04$ & $96 \pm 4$ & 0.995 & - & - & - \\
\hline DIA & $0.60 \pm 0.04$ & $12.0 \pm 0.9$ & 0.984 & $0.62 \pm 0.05$ & $26 \pm 2$ & 0.976 & - & - & - \\
\hline HAT & $1.22 \pm 0.07$ & $24 \pm 3$ & 0.909 & $0.82 \pm 0.06$ & $28 \pm 1$ & 0.980 & $0.58 \pm 0.01$ & $1.48 \pm 0.03) \times 10^{3}$ & 0.999 \\
\hline PROP & $1.00 \pm 0.01$ & $224 \pm 10$ & 0.996 & $0.96 \pm 0.01$ & $389 \pm 9$ & 0.999 & - & - & - \\
\hline
\end{tabular}

${ }^{a}$ Results correspond to the average of a duplicate of experiments.

for the HDTMA-VT 1.0 material, but when the parameter is normalized to the organic carbon content $\left(K_{O C}\right)$, the differences between the two vermiculites are no longer significant, confirming the key role that the organic phase plays on the sorption of these compounds. For DIA and HAT the desorption isotherms were not linear in the range of concentrations studied, so that the $K_{d}$ values were computed only for initial points of the isotherm, up the initial concentration of $250 \mu \mathrm{g} \mathrm{L}^{-1}$. The $K_{O C}$ values for DIA and HAT show that these compounds were more strongly retained by the HDTMA-VT ${ }_{0.5}$ material. Because DIA is the most water-soluble compound, and HAT may be partially protonated at the $\mathrm{pH}$ of the experiment (Table 3), the higher $K_{O C}$ cannot be attributed only to a higher affinity of these compounds by the organic phase. To a certain extent, the behavior of DIA may be explained by the larger surface area of the HDTMA-VT ${ }_{0.5}$ material (Table 3), whereas the behavior of HAT may be related to the availability of ion exchange sites because only a half of the total CEC was used to exchange with the alkylammonium salt.

The desorption study revealed that the sorption process of AT, DEA, DIA, HAT and PROP onto HDTMA-VT is reversible in aqueous medium, as evidenced in Figure 1, which shows desorption curves overlapping the sorption ones. The low degree of hysteresis is also evidenced by the proximity of $K_{f}, K_{d}$ and $K_{O C}$ parameters when compared for sorption and desorption processes for the same compounds and sorbent. Such a behavior suggests that the organically modified vermiculites have potential application in herbicide formulation with controlled release of the active component. Additionally, because the compounds exhibited different affinities by the sorbents and were desorbed in aqueous medium, another potential application is the development of stationary phases for chromatographic columns that could be eluted using water as mobile phase. ${ }^{37}$

\section{Conclusions}

Incorporation of HDTMA onto vermiculite enhanced significantly the sorption capacity of this clay mineral for the herbicides atrazine and propazine. The sorption capacity was also enhanced for the atrazine metabolites deethylatrazine and deisopropylatrazine. On the other hand, sorption of hydroxyatrazine was significantly diminished because the major binding mechanism for this metabolite is electrostatic attraction and hydrogen bonding to the silanol groups of the clay surface. The partition model was suitable to represent the sorption isotherms of all compounds onto the modified clay minerals, suggesting that non-specific interactions occur between the solutes and the organic phase adsorbed onto the clay mineral. A desorption study performed in water using $24 \mathrm{~h}$ of contact time revealed a low degree of hysteresis, indicating an elevated reversibility of the sorption process. This implies

Table 7. Values of distribution coefficient $\left(K_{d}\right)$ and distribution coefficient normalized to the organic carbon content $\left(K_{O C}\right)$ obtained in the desorption experiment of AT, DEA, DIA, HAT an d PROP from the HDTMA modified vermiculites

\begin{tabular}{|c|c|c|c|c|}
\hline \multirow[b]{3}{*}{ Compound } & \multicolumn{4}{|c|}{ Materials } \\
\hline & \multicolumn{2}{|c|}{ HDTMA-VT $_{0.5}{ }^{\mathrm{a}}$} & \multicolumn{2}{|c|}{ HDTMA-VT $_{1.0}{ }^{a}$} \\
\hline & $K_{d} /\left(\mathrm{L} \mathrm{kg}^{-1}\right)$ & $K_{O C} /\left(\mathrm{L} \mathrm{kg}^{-1}\right)$ & $K_{d} /\left(\mathrm{L} \mathrm{kg}^{-1}\right)$ & $K_{O C} /\left(\mathrm{L} \mathrm{kg}^{-1}\right)$ \\
\hline $\mathrm{AT}$ & $116 \pm 4$ & $1009 \pm 35$ & $174 \pm 2$ & $921 \pm 11$ \\
\hline DEA & $59 \pm 3$ & $513 \pm 26$ & $100 \pm 3$ & $529 \pm 16$ \\
\hline DIA & $56 \pm 9$ & $487 \pm 78$ & $39 \pm 1$ & $206 \pm 5$ \\
\hline HAT & $45 \pm 5$ & $391 \pm 43$ & $49 \pm 3$ & $259 \pm 16$ \\
\hline PROP & $216 \pm 7$ & $1878 \pm 61$ & $390 \pm 7$ & $2063 \pm 37$ \\
\hline
\end{tabular}

a Results correspond to the average of a duplicate of experiments. 
that the organically modified vermiculites have potential application in the elaboration of controlled release herbicide formulations, as well as in the preparation of stationary phase for water-only liquid chromatography. ${ }^{37}$

\section{Acknowledgments}

Authors are grateful to FAPESP, CNPq and CAPES for financial support and fellowships.

\section{References}

1. Sindag, Sindicato Nacional da Indústria de Produtos para Defesa Agrícola, http://www.sindag.com.br, accessed in October 2004.

2. Laabs, V.; Amelung, W.; Pinto, A.; Altstaedt, A.; Zech, W.; Chemosphere 2000, 41, 1441.

3. Townsend, M.A.; Young, D.P.; Intern. J. Anal. Chem. 2000, $78,9$.

4. Graymore, M.; Stagnitti, F.; Allinson, G.; Environ. Intern. 2001, $26,483$.

5. Moorman, T.B.; Jayachandran, K.; Reungsang, A.; Soil Sci. 2001, 166, 921.

6. Loiseau, L.; Barriuso, E.; Environ. Sci. Technol. 2002, 36, 683.

7. Kolpin, D.W.; Thurman, E.M.; Linhart, S.M.; Sci. Total Environ. 2000, 248, 115 .

8. Sposito, G.; The Chemistry of Soils, Oxford University Press: New York, 1989.

9. Mc Bride, M.B.; Environmental Chemistry of Soils, Oxford University Press: New York, 1994.

10. Boyd, S.A.; Mortland, M.M.; Chiou, C.T.; Soil Sci. Soc. Am. J. 1988, 52, 652.

11. Laird, D.A.; Barriuso, E.; Dowdy, R.H.; Koskinen, W.C.; Soil Sci. Soc. Am. J. 1992, 56, 62.

12. Konstantinou, I.K.; Albanis, T.A.; Petrakis, D.E., Pomonis, P.J.; Water Res. 2000 34, 3123.

13. Herwig, U.; Klumpp, E.; Narres, H.; Schwger, M.J.; Appl. Clay Sci. 2001, 18, 211.

14. Celis, R.; Hermosín, M.C.; Carrizosa, M.J.; Cornejo, J.; J. Agric. Food Chem. 2002, 50, 2324.

15. Prost, R.; Yaron, B.; Soil Sci. 2001, 166, 880.

16. Jiang, JQ.; Zeng, ZQ.; Chemosphere 2003, 53, 53.
17. Krishna, B.S.; Mahadevaiah, N.; Murty, D.S.R.; Jai Prakash, B.S.; J. Colloid Interface Sci. 2004, 271, 270.

18. Matthes, W.; Kahr, G.; Clays Clay Miner. 2000, 48, 593.

19. Meier, L.P.; Nueesch, R.; Madsen, F.T.; J. Colloid Interface Sci. 2001, 238, 24.

20. Sheng, G.; Xu, S.; Boyd, S.A.; Soil Sci. Soc. Am. J. 1999, 63, 73.

21. Krishna, B.S.; Murty, D.S.R.; Jai Prakash, B.S.; Appl. Clay Sci. 2001, 20, 65 .

22. Sharmasarkar, S.; Jaynes, W.F.; Vance, G.F.; Water, Air, Soil Pollut. 2000, 119, 257.

23. Bartelt-Hunt, S.L.; Burns, S.E.; Smith, J. A.; J. Colloid Interface Sci. 2003, 266, 251.

24. Lee, S.Y.; Kim, S.J.; Chung, S.Y.; Jeong, C.H.; Chemosphere 2004, 55, 781 .

25. Herrera, P.; Burghardt, R.; Huebner, H.J.; Phillips, T.D.; Food Microbiol. 2004, 21, 1.

26. Vimond-Laboudigue, A.; Baron, M.H.; Merlin, J.C.; Prost, R.; Clay Miner. 1996, 31, 95.

27. Socías-Viciana, M.M.; Hermosin, M.C.; Cornejo, J.; Chemosphere 1998, 37, 289.

28. Cruz-Guzmán, M.; Celis, R.; Hermosin, M.C.; Cornejo, J.; Environ. Sci. Technol. 2004, 38, 180.

29. El-Nahhal, Y.; Undabeytia, T.; Polubesova, T.; Mishael, Y.G.; Nir, S.; Rubin, B.; Appl. Clay Sci. 2001, 18, 309.

30. Polubesova, T.; Nir, S.; Rabinovitz, O.; Borisover, M.; Rubin, B.; J. Agric. Food Chem. 2003, 51, 3410.

31. Abate, G.; Masini, J.C.; Coll. Surf. A 2003, 226, 25.

32. Hesse, P.R.; A Textbook of Soil Chemical Analysis, John Murray Publishers: London, 1971.

33. Klapyta, Z.; Fujita, T., Iyi, N.; Appl. Clay Sci. 2001, 19, 5.

34. Dean, J.R.; Wade, G.; Barnabas, I.J.; J. Chromatogr. A 1996, 733, 295.

35. Steinheimer, T.R.; J. Agric. Food Chem. 1993, 41, 588.

36. Vermeulen, N.M.J.; Apostolides, Z.; Potgieter, D.J.J.; J. Chromatogr. 1982, 240, 247.

37. Foster, M.D.; Synovec, R.E.; Anal. Chem. 1996, 68, 2838.

Received: November 18, 2004

Published on the web: July 14, 2005

FAPESP helped in meeting the publication costs of this article. 